is a purpose which Lord Grey himself would have applauded, for he took much interest in the Museum, and was concerned about the upkeep of the many valuable and historically interesting collections which it contains. The Museum itself was built in 1884 to house the natural history collections of the Society, and with subsequent additions it has cost approximately $£ 45,000$. But the cost of upkeep and staffing is more than the Society can bear, even although the membership is now greater than at any time during the hundred and six years of the Society's existence. A sum of $£ 1,000$ has been promised anonymously if three other donors are each prepared to subscribe a similar amount, but it is to the generosity of the many lovers of Nature, and particularly those of the north of England, that Lord Armstrong and the Society look for the safeguarding of the Museum and its collections.

\section{Explorations in Ellesmere Island}

The Oxford University Arctic Expedition of 1934 35 under Dr. N. Humphreys was forced to winter at Etah in north-western Greenland instead of on Ellesmere Island ; but during the summer of this year they split up into small parties, each accompanied by Eskimo, and explored various parts of the north and centre of Ellesmere Island. Three articles on their work have appeared recently in The Times. An attempt to cross the Grinnell Land ice-sheet failed, but a crossing was made to the south by the narrow isthmus between Flager and Bay fjords, thus linking up with Isachsen's former work on the west coast. A more important joumey was made in Grant Land from Fort Conger, Greely's camp of half a century ago, via Lake Hazen to the lofty United States Range. From a summit of $9,000 \mathrm{ft}$. there was a good view clear to the north. The country seems to be entirely mountainous and difficult to cross. The lofty ranges to the northward were named the British Empire range. They appear to flank the northern side of Ellesmere Island, and their relation to the Challenger Mountains farther west, discovered in 1876 by Aldrich, will be of interest when revealed. These mountains are probably related to the Caledonian foldings of northern Greenland. A third party carried out some surveys in Scoresby Bay, which hitherto had been inadequately examined. The expedition returned to England in October bringing large collections.

\section{Organisation of the Coal Industry}

SIR Harold Hartlex, addressing the Institution of Chemical Engineers on October 20 on "Our Nation's Coal Resources", surveyed the changes which, during the last twenty-five years, have so profoundly affected the prosperity of the British coal industry. $\mathrm{He}$ pointed out the need which has been disclosed for the National Coal Survey undertaken by the Fuel Research Board, and stated that the value of the work of the Survey is becoming more obvious as it progresses. He advocates extending the Survey to examine the suitability of coals for the different industrial purposes, so as to discover where need for conservation exists. Fuel economy in utilisation and other circumstances have reduced the production of coal ; but methods of mining have made great progress, and both circumstances reduce the number of mine workers. Methods of transportation and distribution have not kept pace with the improvement with the methods of mining. Sir Harold condemned the widespread ownership of private waggons as a burden on cost of distribution and advocated a unification of interests at least up to the point at which coal is to be transferred to the consumer. A rational system of grading should replace trade practice of selling by description. Intensified research on the fundamental nature of coal was urged, and indeed the factors which seem to Sir Harold most promising are more research and better organisation. The latter may be unpalatable to some individualists, but seems to be inevitable.

\section{The Press and the Post Office}

IN the course of an address to the Post Office Telegraph and Telephone Society given at King George V Hall, St. Martin's le Grand, London, on November 18, by Mr. J. H. Brebner, press officer of the Post Office, it was emphasised that the development of the Press has been closely allied to the progress of the Post Office. The Post Office can claim a great share in the development of newspapers, for from its establishment, six postal officials entitled 'clerks of the roads' were the first newsagents in Great Britain, and were solely responsible for the distribution of newspapers to all parts of the United Kingdom. These 'clerks of the roads' derived some $£ 8,000$ a year from the sale of newspapers, $£ 6,000$ of which was used by the Post Office for the payment of pensions and increases of salaries to Post Office servants who were inadequately paid. At the beginning of the nineteenth century, the private telegraph companies maintained a press bureau which supplied the newspapers with general news. The newspapers, however, desired to organise their own press agencies on the ground that they were the better judges of the news the public required. Since the telegraph companies would not give up their press bureau, the newspaper proprietors joined the growing agitation for the nationalisation of the telegraph system. The Electric Telegraphs Bill was passed in 1868, and the State accordingly acquired the telegraphs. A special 'News Division' was created at the Central Telegraph Office, London, and was maintained until 1930, when the extended use of the telephone by the Press, and the leased telegraph lines to press agencies and newspapers, rendered this section with its special press wires unnecessary. The Press has taken full advantage of each step in the progress of communications brought about by the Post Office, and the rapid development of the telephone service, since its acquisition by the State in 1912, has enabled the speedier transmission of news not only from all parts of Great Britain, but also to and from all parts of the world.

\section{Imperial Chemical Industries, Ltd.}

Mr. Justice Eve has allowed the petition of Imperial Chemical Industries, Ltd,, to confirm a 
reduction of capital from $£ 95,000,000$ to $£ 89,565,859$, the petition being opposed by a committee representing more than 13,000 holders of Deferred shares. In evidence, Sir Albert Wyon, chartered accountant, agreed that the company is spending large sums of money on research which have yielded valuable returns. These returns appear in the accounts in the shape of increased revenue. In this connexion, it is of interest to recall that, when this great combine was formed, NATURE, in a leading article (January 29,1927, p. 149), stressed its importance from the point of view of scientific research: "Of special interest, fully recognised by the promoters of the trust, is the question whether it will be possible to improve methods and results in scientific research. The record of the constituent companies in this respect is creditable enough, and the work they accomplished during the War earned the gratitude of the nation. But combination must tend towards greater economy and greater efficiency."

\section{Cornish Engines Preservation Fund}

CoRnWaLl occupies a unique place in the industrial history of Great Britain, owing to its contributions to the advancement of mining and the development of the steam engine. The natural pride Cornishmen take in the achievements of the inventors and engineers of the county has found expression in various ways, and a scheme has now been set on foot for preserving, before it is too late, some of the few remaining Cornish beam engines. At a meeting held at Murdock House, Redruth, on October 15, a committee was formed to further the scheme, and an appeal has been made for funds for the purchase of a winding engine at Levant Mine, designed nearly a century ago by Francis Mitchell, and probably constructed at Copperhouse Foundry, Hayle. The engine, which is of the beam type, has a cylinder $24 \mathrm{in}$. in diameter with a stroke of $4 \mathrm{ft}$. As the mine, after a life of 110 years, has been closed down, the engine can be purchased at scrap value and arrangement can be made for its preservation in situ with a right of way to it, the total sum required for the purchase of the engine, repairs to the engine house and for maintenance being estimated at $£ 300$. The honorary secretaries to the committee are $\mathrm{Mr}$. W. T. Hooper, of Falmouth Observatory, and Mr. W. A. Michell, Couch Lane, Redruth, while the honorary treasurer is Mr. H. Michell, of Barclays Bank, Falmouth, to whom subscriptions should be sent.

\section{Quarterly List of Scientific Books}

The Association of Special Libraries and Information Bureaux, 16 Russell Square, London, W.C.1, has recently issued a book list which is the first of a series of quarterly recommendations of recently published scientific and technical books $(10 s .6 d$. a year for non-members). The main object of the list is to provide public and other libraries with a selected list of recent scientific and technical books, and the list has been compiled with the assistance of more than sixty specialist organisations which are able to assess the relative merits of new publications in their own fields. Only books in the English language, and, with few exceptions, those published in the last six months, have been included. No attempt has been made to introduce detailed classification, the books being listed under broad main headings, such as General Science and Technology; Chemistry and Chemical Technology ; Physics ; Metallurgy ; Medicine, Public Health and Nutrition; Communications and Transport, etc. The books are further sub-divided into those suitable for general readers, books of an intermediate character or suitable as textbooks for students, advanced or highly technical books, and dictionaries, directories or encyclopædias and the like. The lists should thus be of real value to specialist, as well as to public, librarians, in dealing with the difficult problem of book selection, particularly in fields of which the librarian himself has no special knowledge.

\section{Maimonides}

Dr. M. GASTER delivered a lecture on "Maimonides and his Works" at a meeting on November 14 of the Royal Asiatic Society in conjunction with the Society for Old Testament Study. He said that Maimonides was a man of strong faith which deeply influenced his activity. Fully conversant with the Hebrew and Arabic literature of the time, he displayed a threefold activity. First, his legal activity consisted in compiling for the first time a comprehensive code of laws which has remained the basis of Judaism to this very day, and prevented it from splitting up into sects. Secondly, his medical activity was intended to prove, besides furthering and stimulating medical research, that there is no incompatibility between science and faith ; indeed, that they assist one another. Thirdly, his philosophical activity was intended to reconcile the tenets of faith with philosophic speculation. $\mathrm{He}$ endeavoured to answer some of the fundamental problems of human life, such as the existence of God, the problem of creation, the relation between God and man, revelation, sin and evil, punishment and reward, and immortality. With slight modification, the answers which he gave retain their value even at the present time.

\section{Sir John McLennan, K.B.E., F.R.S.}

IN the obituary notice of Sir John McLennan published in Nature of October 19 (p. 633), it was stated that he went from Toronto to Cambridge with an 1851 Exhibition Scholarship. Prof. A. S. Eve now informs us that this statement is not correct. Dr. E. F. Burton, who succeeded Sir john at Toronto, has written : "Although most of the men who were at the Cavendish with Dr. McLennan held 1851 Exhibition Scholarships, he did not have one himself. As a matter of fact, he resigned his position at Toronto in order to go abroad entirely at his own expense. It was in the nature of a gamble for him at that time as his resources were very meagre, but he realised that this was the only possible course to take if he wanted to work in what was then modern physics. He was undoubtedly moved to do this by the meeting of the British Association for the Advancement of Science in Toronto in 1897, as it was just after this that he went to England." 